\title{
Rough riding: Aboriginal participation in rodeos and travelling shows to the 1950s
}

\author{
Kathryn M Hunter
}

On Saint Patrick's Day 1906, 3,000 people, including the Governor of New South Wales, squeezed into a 'tight little box of an arena' in Sydney's Rawson Place to watch a rough riding competition between two of the most famous riders of the time: Lance Skuthorpe, 36, and Billy Waite, a 23-year-old Aboriginal man. For this contest they had the choice of six horses, including the most notorious buckjumper of the day, 'Bobs'. A scroll trailed down over the railing beside the Governor, listing the 800 men who had been thrown by Bobs. The Evening News wrote that Waite was in his prime as 'a firstclass horseman'. According to the newspaper, Waite was 'as clever as a fox terrier' and 'as active as a panther', because 'he disdains to crawl through the slip-rails [vaulting them instead] and jumps from the ground into the saddle on a bucking horse'. ${ }^{1}$ According to historian Jenny Hicks, it was 'the match of the universe'. Skuthorpe, 'even at 36 years of age, was considered to be Australia's best buckjump rider', while Billy Waite was considered 'to be the only other man at the time in his class, and Bobs to date was unridden'. ${ }^{2}$ According to Waite:

By the time I was on him three quarters of a minute I was leg weary and sick and I lost my seat ... It was the roughest ride I ever struck with an English saddle. Bobs is a tough 'un. I've ridden some warm mokes in West Australia, but they soon give in. With Bobs, the longer you stick to him, the worse he gets. ${ }^{3}$

In front of a capacity crowd Waite rode all three of Skuthorpe's horses, and Skuthorpe rode Bobs to a standstill. Skuthorpe, who refused to ride the other two mounts, forfeited the competition, and perhaps the $£ 1000$ prize money, to Waite (though there is some doubt that the prize money ever existed).

This was both a typical scene and an unusual one. Across eastern Australia in buckjump competitions, Aboriginal riders showed their style. This particular competition was unusual for the large amount of prize money offered and because it happened within a stone's throw of Central Railway Station. This was also a 'celebrity event'; the arena was packed with Sydney-siders, including the Governor of New South Wales, and hundreds more had been turned away at the gate. This competition featuring a

Evening News cited in Pollard 1966: 132.

Here 'unridden' means that no one managed to stay on Bobs. Hicks 2000: 46-47.

Billy Waite in The Referee cited in Hicks 2000: 46. See also Pollard 1966: 131-135. 
celebrity Indigenous rider who stood to win $£ 1000$ was most unusual perhaps because it was held shortly before the most repressive and damaging 'protection' legislation was introduced in New South Wales in 1909. The spectacle of a packed audience and an admiring press focusing on an Indigenous man entering the ring that day was perhaps a more intense version of a regular feature of life throughout rural eastern Australia in the first half of the 20th century: the rodeo, in which Aboriginal and non-Aboriginal horsemen pitted themselves against each other and against the horses.

This article is a preliminary investigation of the participation of Aboriginal men in rodeo in 20th-century eastern Australia. Drawing on the work of Richard Broome and Alick Jackomos on sideshow alley and tent boxers, as well as on that of Peter Iverson on Native American rodeo, I began to explore Indigenous participation in travelling shows and more specifically rodeo up to the 1950s. Aboriginal participation in shows was very clear, despite the transitory nature of shows and the resulting slim, fragmented evidence. What I managed to garner from the fragments I found mainly in the popular press of the day reinforces Richard Broome's argument in respect of Aboriginal tent boxers that '[a]lthough these performances of power by Aboriginal men might be transitory and subsequently overlaid by experiences of injustice and discrimination ... [they] contributed positively to the fashioning of Aboriginal self-esteem and identity in a difficult cross-cultural world' ${ }^{4}$ Broadly speaking, the skills acquired by Indigenous men in the cattle industry, particularly horsemanship, were displayed at bush carnivals (later to be known by the American term 'rodeo') and became both features of sideshows and performances in their own right. Aboriginal and non-Indigenous stockmen alike used these carnivals as a way of supplementing their incomes, sometimes with considerable prize money. From my research to date, Aboriginal men who participated in these carnivals and shows found varying degrees of acceptance amongst other riders and showpeople. Aboriginal amateur riders, vying for prize money sometimes found admiration and acceptance in the ring, while professional show riders, by and large, seem to have found community and acceptance that extended beyond the ring to dining tables. They participated to display their athleticism and skill and to earn respect. As Broome has argued for Aboriginal tent-boxers, 'race was transcended by the magnetism of ... [their] masculinity' and, in this specific case, by Aboriginal men's horsemanship. ${ }^{5}$ As with boxers, however, the associations between Indigenous men and rodeo were not all positive. On the one hand rodeos were exhibitions of Aboriginal prowess, prestige and prize monies, while, on the other hand, there was the inevitable reinforcement of the connection between Indigenous masculinity, Nature and physicality. Indeed, these performances cannot be separated from the 19th-century context of displays by and of Aboriginal people that emphasised primitivism and savagery through a focus on Aboriginal bodies and 'traditional' skills. ${ }^{6}$

The ambivalence with which Europeans regarded even their most admired Aboriginal workers and companions was evident within the world of horsemen even up to the 1950s. Other authors have documented the difficulty some non-Indigenous people had reconciling their experiences of companions and workers who were dutiful and

\footnotetext{
Broome 1996: 2.

Broome 1996: 17

Poignant 1997; Scott and Laurie 2007; Sampson 2000.
} 
often became integral parts of the family, with the dominant cultural and historical view of Aboriginal people as cunning or untrustworthy. This is especially obvious in cases of Aboriginal domestic service where Indigenous women cared for white children and were a significant source of emotional support for white women, yet could be treated poorly and paid a pittance. ${ }^{7}$ The Roughriders' Association magazine, Hoofs and Horns, showed this ambivalence by dividing Aboriginal men into 'station blacks' those it regarded as having successfully assimilated (albeit in a limited way) - and 'wild blacks', those who had not, those who remained outside the pastoral industry. It must also be noted that their regard for Aboriginal horsemen and the offer of equal prize money to both Indigenous and non-Indigenous riders did not translate into a concerted push for equal wages for Indigenous pastoral workers.

This article is concerned with Aboriginal men's experiences. While it has been well documented that Aboriginal women were stockworkers and horsewomen, ${ }^{8}$ this did not, as far as I have been able to ascertain, translate into Aboriginal women's participation in bush carnivals or in the separate Aboriginal buckjump events. ${ }^{9}$ Hoofs and Horns often reported results from women's rough riding and other events like Flag Racing, but, curiously, the participants were exclusively non-Indigenous. As the 20th century wore on, women worked less as stockworkers in southern Queensland and New South Wales, and this may be one reason for their absence as riders in shows. Given the legislative pressures on Aboriginal families, it may also be that women were reluctant to do anything that might attract attention to themselves or their children. For the purposes of this article, the experiences of Aboriginal women and their absence from the prestige horse events is a reminder that masculinity was a powerful force in rodeo.

Aboriginal participation in the cattle industry is not a simple story. Conditions in the industry varied enormously across Australia between the 1890s and the 1940s; historians have documented examples of poverty and exploitation among Aboriginal cattle workers, but they also document stations with generous rations and a strong community spirit. ${ }^{10}$ Peggy Brock has argued that Indigenous interaction with pastoral industries in southern and central Australia, while allowing for the maintenance of cultural and religious practices, did not bestow advantages on Aboriginal workers. She suggests that pastoralists 'did not directly interfere with the way their workers organised their lives ... [but that] literacy and numeracy skills which might allow Aboriginal workers to change their working conditions were not imparted' ${ }^{11}$ Heather Goodall writes that, because of a shortage of white labour, Aboriginal pastoral workers in New South Wales had achieved largely peaceful relationships with pastoralists in the latter part of the 19th century and that by the turn of the 20th century they constituted roughly a third of the New South Wales pastoral workforce. Pastoralists gained tal-

7. See for example McGrath 1987; Walden 1995.

8. See for example May 1994: 51-52; McGrath 1987; Reynolds 1990; Brock 1995: 102-114; Kidd 2006. See also a story about teenage Aboriginal drover, Irene Turner, in Hoofs and Horns, September 1951: 47.

9. See, for example, a report on the Negri Races which detailed the 'events for both blacks and whites' and the winners of the 'black boys' section', Hoofs and Horns, November 1951: 51.

10. McGrath 1987; May 1983; May 1994; Reynolds 1990; Bolton 1981.

11. Brock 1995: 107. 
ented and willing workers cheaply during this period that Goodall calls 'dual occupation', in which Indigenous people continued to have free access to their traditional lands through their work. When white labour became more readily available in the 20th century, however, pastoralists pressed home their advantage and traded access to land through continuing employment for poor or non-existent wages for Aboriginal workers. ${ }^{12}$ Aboriginal groups continued to do stock work for a variety of reasons, which included the challenge to maintain group esteem and identity and, more pragmatically, to remain as close to traditional lands as possible and to take advantage of white labour shortages. ${ }^{13}$ Aboriginal stock workers would be denied equal pay with white workers until the late 1960s. ${ }^{14}$

The focus of the historiography of Aboriginal participation in the cattle industry has been on work and the relationships, formal or otherwise, to land. Involvement in pastoralism, however, also led to participation in competitive displays of stockmen's skills. Jenny Hicks has argued that wherever in the world there was a large cattle industry, rodeo events naturally developed. In Australia, by the 1890s, 'rough riding had become such a popular spectacle that it began to grow in two separate but intricately entwined directions': one, the weekend bush carnivals for horsemen and women from stations and properties that eventually became rodeos; and the other the rough riding exhibitions and competitions that were public entertainment in towns and cities along with travelling circuses, Wild West and buckjumping shows. These shows had permanent touring staff and invited local challengers from the audience to participate. ${ }^{15}$ Aboriginal men used travelling shows and bushmen's carnivals as ways of supplementing meagre (or non-existent) wages. In both amateur and professional touring shows, Aboriginal riders could gain approval and admiration unknown outside the ring.

Aboriginal performers and horsemen had long entertained non-Indigenous audiences. Shows and spectacles in Australia provided an arena in which Indigenous people demonstrated skills and courage that were much admired, albeit mediated through notions of primitivism and the 'upside down world' of the circus, and they formed a context within which Aboriginal rough riders' performances were understood by non-Indigenous people. Mark St Leon's documentation of Australian circus history reveals Aboriginal trick-riders and acrobats in the earliest of the colonies' circuses, together with performers impersonating other of the world's Indigenous peoples. ${ }^{16}$ It is difficult in the 19th and early 20th centuries to divorce Aboriginal horsemanship and performance from the wider context and meaning of Aboriginal display. Aboriginal participation in spectacles was often understood through tropes of primitiv-

12. Goodall 1996: 57-66. Peter Iverson argues a similarly mixed relationship between Native Americans and cattle ranching. He argues that 'cattle ranching could contribute to tribal identity and individual self-esteem' (Iverson 1994: 13-14).

13. See McGrath 1987 and, for an international perspective, Iverson 1994.

14. McGrath 1987: 122ff.

15. Hicks 2000: 21-22. See also Iverson and MacCannell 1999: 5-6 for a similar description of the origins of Indian rodeo.

16. In 1857, for example, James Ashton appeared during a performance as 'Blackfoot, the Native American Indian' (Cannon 1997: 39). For further detail on the history of Australian circus, see Mark St Leon's article in this volume. See also Ramsland 1993. 
ism and 'wildness'. In the late 19th century, Aboriginal people were displayed in formal and theatrical ways, often alongside animals, in various 'Wild Australia' shows and 'Ethnological Congresses', which capitalised on the exotic appeal of Indigenous peoples. ${ }^{17}$ In the Ethnological Congress of Barnum's Circus in 1883 a troupe of nine Queensland Aborigines led the Grand Parade with the Zulu troupe and Jumbo the elephant. ${ }^{18}$ The purported characteristics of Aboriginal people were announced in advertisements as a combination of bloodthirstiness to be feared and of outstanding bushmanship to be admired. RA Cunningham touted his Aboriginal troupe as 'RANTING MAN EATERS!' and 'veritable blood-thirsty beasts' but also as 'Queensland Black Trackers' and 'celebrated bushmen'. ${ }^{19}$ The 'Wild Australia' shows tended more towards the depiction of Aboriginal bush skills and weapon displays. Archibald Meston, Southern Protector of Aborigines in Queensland in the 1890s, put together a 'Wild Australia' show, which performed before the Queensland Governor, Lord Lamington; and in 1901, Meston took his troupe to Sydney for the re-enactment of Cook's landing. ${ }^{20}$ These shows featured Aboriginal artefacts and weaponry, Wild West-type enactments, and large Aboriginal men (their physique always drew comment) who danced, reenacted frontier skirmishes and staged mock fights using native weapons. ${ }^{21}$ While displays of Aboriginal 'traditional' skills and the theatre of frontier conflict continued into the 20th century, the conflict depicted was no longer necessarily between Indigenous and non-Indigenous people. Influenced heavily by the American Wild West Shows, shows like 'Wild Australia' featured in its Pageant of Empire performances in London 1911, 'Exciting Kangaroo Chase by Australian Aborigines', "“The Horse Thief": A dramatic seena [sic], illustrating realistically, the fate meted out to Outlaws of the Bush' and, for its grand finale, 'The Kelly Gang'. ${ }^{22}$

At local agricultural and horticultural shows Aboriginal people were put on display but also actively participated in these community events. ${ }^{23}$ Aboriginal people voluntarily displayed a variety of skills and ceremonies at shows and were often paid for doing so. In 1853, for example, 'the annual "corroboree" held in Queanbeyan, New South Wales, was watched by two-thirds of the town's population, who paid sixpence a head to Jimmy Taylor [a Ngunnawal man] for the privilege'. ${ }^{24}$ In Wentworth, New South Wales, 'the town's aborigines danced a corroboree to celebrate the inaugural agricultural show in $1885^{\prime}{ }^{25}$ Sisters Maisie Kelly and Hazel Vale said that Aboriginal displays were regular features of the Armidale Show, school shows and fundraisers in the late 1930s. The displays contained traditional elements such as boomerang-throwing and corroborees, but could also include popular songs played on the concertina, piano, steel guitar and violin. ${ }^{26}$ Aboriginal musician Ted Thomas recalled his early

\footnotetext{
17. For discussion of these see Walker 1997; Poignant 1997; Scott and Laurie 2007. For a discussion of World's Fairs see Greenhalgh 1988.

18. Poignant 1997: 28.

19. Poignant 1997: 29

20. Walker 1997: 39-40.

21. See Sampson 2000, Appendix H.

22. McConville nd: 11.

23. See for example Scott and Laurie 2007.

24. Jackson-Nakano 1994: 47. See also Broome 1995: 171.

25. Mant 1985: 109.
} 
days in a 'gum leaf band' in the 1920s. The band toured Victoria extensively and played at the Palais Royale in Melbourne to an audience of white people 'in big ball dresses' ${ }^{27}$ Increasingly, Aboriginal performers melded traditional practices and music with more contemporary skills, instruments and songs, but their motives of earning an income and garnering admiration were constant.

Within this wider context of performance, then, rodeos, travelling shows and bush carnivals featured in the lives of many people. Rodeo and buckjumping competitions often coincided with the circuit of travelling shows and in the 1930s, in particular, local Agricultural Show associations in south-eastern Australia organised rodeos as part of the entertainment. ${ }^{28}$ The cross-over between rodeo and other kinds of shows was such that I have been reluctant to separate out a more narrowly defined idea of rodeo or buckjumping competitions. Tom McNeven, an Aboriginal drover and station hand, recalled going to town at 'showtime' as a child to see buckjumping shows featuring European performers Tex Morton, Kitty Gill, Lance Skuthorpe, Lance Jnr and Violet Skuthorpe. ${ }^{29}$

In oral accounts and reminiscences of Aboriginal stockworkers there are recurring narratives linking work and displays of horsemanship, and many men interviewed about their working lives described rough riding. Tom Roberts grew up in northern New South Wales and began going to buckjumping competitions as a young man. ${ }^{30}$ Billy Crawford said his brother Cyril Crawford 'was a good horseman', who rode in the show at Walcha, winning the buckjump competition before going to Armidale, where he was beaten by Billy Cleveland, 'a dark bloke ... from Queensland'. Crawford, who spent his time trying his luck in the boxing tent, also recalled his uncle Billy Lovelock as a great buckjump rider who rode 'in the yards', but never in shows. ${ }^{31}$ Clarrie Grogan also grew up 'mad on rough riding', but he too chose to perform in the boxing text. ${ }^{32}$

A further recurring theme in reminiscences about rough riding was the story of the 'star rider'. While not all stories about star riders can be substantiated, many Aboriginal men were referred to in this way. When Richard Broome tried to flesh out the life of an itinerant Aboriginal man known as 'Mulga Fred', the most substantive extant information he found was of his career as a whipcracker and rodeo rider. ${ }^{33}$ Mulga Fred began his career with Bronco George's Buckjumping Show in the early 1900s, before joining the Mulder Brothers' Show in 1908 and then moving to Billy Kinnear's Buckjump Show as their star rider about $1911 .^{34}$ As a professional rough rider, Mulga Fred

26. Maisie Kelly and Hazel Vale (nee Archibald), interviewed by Chris Sullivan 1990. Maisie and Hazel are descendants of the New England groups, Nganyaywana, Dainggatti and Gumbainggir.

27. Ted Thomas, interviewed by Chris Sullivan 1987.

28. See for example advertisements for the Patriotic Sports Carnival and Maitland Show, The Referee, 14 February 1900; posters for the Albury Show 1932, Border Morning Mail, 2 September 1932; Grills 1994: 73, 86 for examples from Lance Skuthorpe and Jack Stanton's shows.

29. Tom McNeven, interviewed by Chris Sullivan 1991.

30. Tom Roberts, interviewed by Peter Byers 1987.

31. Billy Crawford, interviewed by Chris Sullivan 1989.

32. Clarrie Grogan, interviewed by Kevin Bradley and Peter Ellis 1990. Clarrie became a professional boxer.

33. Broome 1998: 1-23. 
was successful and much admired. 'One persistent story about [him] is that he won the 1911 Melbourne Coronation Buckjumping Carnival, staged to celebrate King George's ascension to the throne', Broome cautiously noted, ${ }^{35}$ but, as with other aspects of Mulga Fred's life, this claim could not be substantiated. Something of the life of Gunditjmara man Jackie Lovett is also illuminated through his reputation as a 'star rider'. His cousin, Iris Lovett-Gardiner, wrote of him: 'He used to ride for Tex Morton in the rodeos. He was the star rider there for three years. He was the best balanced rider they had ever seen. ${ }^{\prime 36}$ Jackie Lovett's ride at the St Arnaud rodeo was the subject of photos in Hoofs and Horns in 1948, captioned 'Jackie Lovett, the coloured rider from Heywood'. ${ }^{7}$

Several other Aboriginal riders were mentioned in Hoofs and Horns for their superior ability. In 1948 King Costello, 'that fine horseman' and 'this smiling aboriginal':

drew the notorious Mandrake in the first round of the Open. The big grey had thrown three riders of a travelling rodeo at the Ingham Show a few weeks before in a $£ 25$ challenge contest, and excitement ran high as folk waited to see King try conclusions with this mighty bucker. However, Mandrake slipped and fell soon after leaving the crush, and King was partnered with Victory Roll for his re-ride. I fancy this horse was only ridden once before ... However King proved too good for Victory Roll after a great tussle, and rode himself into a ride on Fantan in the final. ${ }^{38}$

Tommy Dodd, 'a tall, lanky, jet black aborigine', was brought to the attention of Hoofs and Horns by the manager of Etadinna Station who claimed that 'no horse could throw him'. Tommy's skill was confirmed by others in the district, 'and there are some very well-known horsemen among them ... [who] maintain he is really "good"'. The article reminded readers that 'Tommy was the boy who rode Token to a standstill at Barrow Creek with spurs and you can ask anybody who has been around that way about it. They say it was the greatest exhibition of buckjumping they had ever seen'. ${ }^{39}$ The report on the Gympie Rodeo of 1948 noted that the 'winner of the Wide Bay Championship Buckjumping was the veteran coloured rider, Peter Byers, whose age is in doubt, but he is believed to be well in the 50s. Peter is a finished rider and a good showman whose antics are well-known and appreciated by the local crowd ${ }^{\prime} .{ }^{40}$

As Colin Tatz has shown, sporting ability has ensured that some Aboriginal men have been recorded by history, even if their biographical details have not. While not necessarily 'star riders' there are many more Aboriginal riders whose names, and sometimes little more, have survived in the historical record because of their skill on a bucking horse. Some of these horsemen are noted by the names Europeans gave them, and nothing further is known about them: Harry Phillips or 'Old Mudgee'; 'Black Tracker'; 'Cliff', 'a mixture of Malaysian and Aboriginal' and 'Mick' who had his leg broken during a display of riding for Sir Sidney Kidman's birthday and so couldn't attend the dinner to which Kidman had invited all his staff. ${ }^{41}$ Other Aboriginal riders

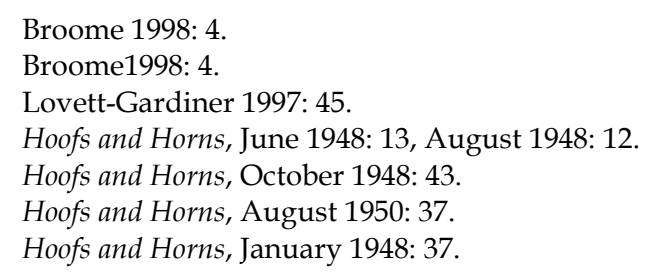


appeared in the photographs of Hoofs and Horns where some were named and others not. The caption under a picture of 'Scobie, a 15-hand gelding, highly prized as a bronc horse on the mustering camp at Keeroongooloo cattle station' named the rider as 'Upperty, King of the Cooper tribe and a fine horseman and cattleman'. ${ }^{2}$ Alwyn Kennedy, Alec Iffley, Bob White, Peter Byers, Walter Mailman and 'his brother' (unnamed) all appeared in various photographs in the magazine during the 1940s. ${ }^{43}$ These photographs were occasionally of posed groups of competing riders but, more often, they were 'displays' of buckjumping, and bullock and steer riding.

The most photographed and reported upon Aboriginal amateur rider of the 1940s was Johnny Cadell. Born at Adelaide River near Darwin (possibly of Larrakia or Woolna descent), Johnny was the son of a noted horseman, Jack Cadell. ${ }^{44}$ Johnny learned buckjumping while working as a stockman with Ted Lowe, an ex-Queensland champion. By the age of 24, Johnny was considered one of the best riders in Australia and featured in the regular Hoofs and Horns column 'Wild Horses and the Men who Ride Them' ${ }^{45}$ Over the next five years, Johnny Cadell's photo appeared in Hoofs and Horns five times including on the occasion in 1950 that he 'scored highest points in the first round of the Australian buckjumping championship' at the Barossa Valley Rodeo, and as the demonstrator for a full-page article entitled 'How to mount correctly' ${ }^{46}$ Even though Johnny was the most recognisable Aboriginal rider to Hoofs and Horns' readers, in this article he is referred to simply as 'a smart stockman', but still the magazine's use him of reinforces the link between display riding and work.

Queensland rider Billy Waite, whom we met at the outset, was probably the best known of the professional rough riders during the early decades of the 20th century. Jack Pollard writes of him:

Waite was considered in [Lance] Skuthorpe's class among roughriders. He was said to have polished his skill by climbing trees in the bush when unbroken horses were about, falling onto the backs of the animals other blacks manoeuvred under the trees, riding them without rope or bridle ... In the show ring one of Waite's acts was to creep about on his hands and knees like a cattle dog after several wild horses had been released. He would move after a horse and with perfect timing [bite] the horse's hind leg like a cattle dog heeling an animal, ducking to miss the ferocious kicks. ${ }^{47}$

While no other source mentions these aspects of Billy Waite's life or act, he was considered Skuthorpe's equal. But, after the 1906 contest with Skuthorpe, Waite's exact movements are difficult to trace. Pollard claims that Waite rode for Skuthorpe in the years before the First World War, but it is not clear exactly when. Waite went out on his own for a brief time and there is a record of Waite's Buckjumping Show appearing in

41. Tatz and Tatz 2000: 233; Pollard 1970: 157; Grills c1994 Oram 1992: 7; Bowen 1992: 10.

42. Hoofs and Horns, January 1951: 49.

43. See Hoofs and Horns, May 1946, October 1948, January 1949, September 1949, October 1949, December 1950.

44. See The Encyclopaedia of Aboriginal Australia 1994.

45. Hoofs and Horns, March 1946: 2.

46. See Hoofs and Horns, May 1946: 3, December 1947: 44, June 1948: 11, June 1950: 41, 'How to mount correctly', December 1949: 42.

47. Pollard 1970: 37-38. 


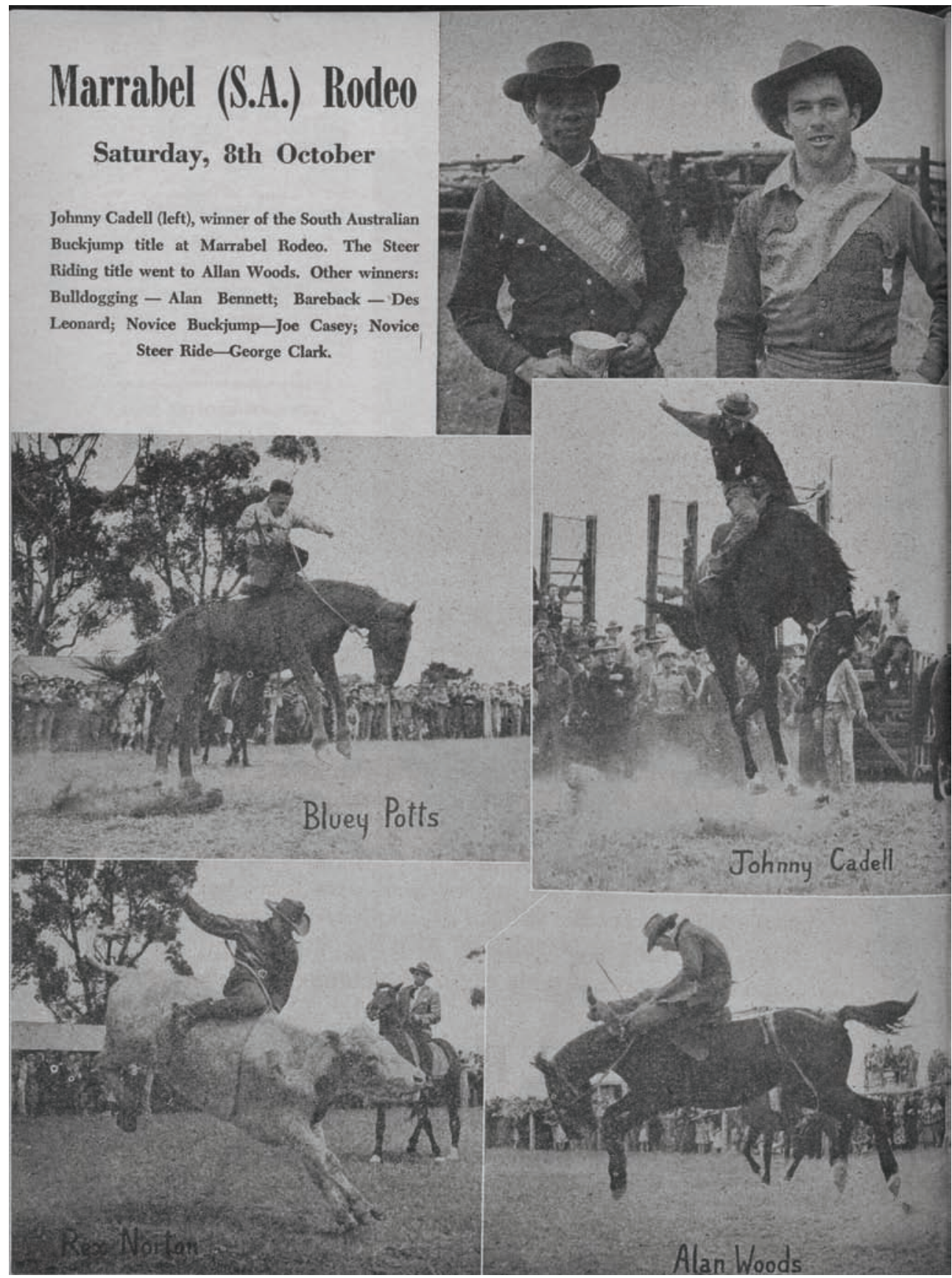

From the pages of Hoof and Horns, 1951, by permission of the National Library of Australia. 
Junee in $1908 .{ }^{48}$ Billy Waite also toured India with Phillip Lytton's Australian Buckjumpers in 1910 when the entire company was purchased by Alf Neave to perform at London's Crystal Palace at the Festival of Empire Pageant in 1911. As well as riding, Waite gave stockwhip and bullock whip demonstrations including one with the 'largest stockwhip in the world' at 60 feet and weighing almost $27 \mathrm{lbs} .{ }^{49}$ What became of Billy Waite after the tour of England is not known. Hicks reports that Waite went to America from England and is thought to have died there. ${ }^{50}$

While Aboriginal horsemen were admired and, in some cases, regarded as some of the finest riders of the early 20th century, the ambivalence towards Aboriginal people in general was also apparent in this milieu. There seems to have been an imaginary divide between 'station blacks' - those who could ride horses and were part of the pastoral workforce - and those who were referred to as 'wild blacks' ${ }^{51}$ Dawn May suggests that there was a physical divide between these two groups in that ' $[\mathrm{b}] \mathrm{y}$ the end of the [19th] century the physical condition of permanently employed station blacks was better than that of blacks leading a traditional lifestyle in the bush ... Besides being better fed, those on stations had access to some medical facilities, rudimentary as they were. $^{, 52}$ May also points to the stubborn ambivalence in European attitudes towards the pastoral workforce. While colonists regarded Aboriginal companions as 'an insurance policy', seeing them as 'most useful servants in the bush, [they] get up the horses in the morning, light fires by night, and know by a sort of instinct if there are any wild blacks in the neighbourhood of their camps', Aboriginal workers were nonetheless never entirely trusted. ${ }^{53}$ There were similar feelings in the horsemen's community. Lance Skuthorpe's biographer notes that while Lance used horsebreaking techniques supposedly learned from Aboriginal people, his brother Amos slept with a revolver strapped to his wrist. Amos Skuthorpe was old enough to remember the revenge killings of local Aboriginal people following the murder of Jack Durack, and the memory of the sudden eruption of racial violence had a lifelong effect on the Skuthorpe brothers. ${ }^{54}$

Further evidence of this ambivalence can be found in the pages of Hoofs and Horns right up to the 1950s where it is difficult to reconcile the treatment of Aboriginal horsemen with the magazine's reporting of other Aboriginal people. The horsemen, although often referred to in paternalistic ways, were reported in the magazine fairly and with due coverage of their skills and winnings. Other articles, however, were disparaging and openly racist, perpetuating myths and stereotypes of the frontier. Proximity to the ring determined attitudes, it seems. The 'mid-point' between these two positions was a story that appeared in 1948, 'You can pick your horse', describing the muster of wild horses for breaking:

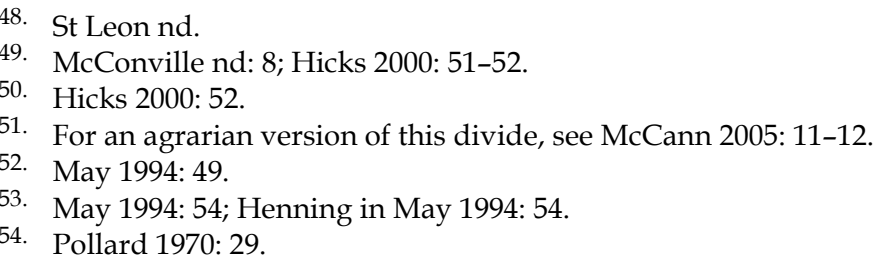


It was interesting to watch the boys choose their best friends for the month to come. Some went for speed, some went for style. But old Charlie, black Charlie, waited his turn; bare-footed, ragged, whiskered and torn-pants Charlie, great rider in his day. ${ }^{55}$

Charlie chose last and so had to choose from the most difficult (but in this world, the most admired) horses: 'The big hearts that tick inside The Banjo and Digger and the like make great transport - if you can stay up top - and Charlie reckoned he was the man to ride them and, what is more, he aimed to ride the best horses in the plant'. Charlie's Aboriginality was obviously an advantage in the eyes of the author:

There must be a sort of understanding between men like the old nigger and horses like The Banjo - the way they talk to each other with attitudes of heels and grunts from time to time; it's not the English language but it's a language, and they both understand it. ${ }^{56}$

When Charlie's work with the three difficult horses was done, 'no one yelled or chiaked or bragged ... but deep down we dipped our lids to the greatest of them - the man who rides his rodeo far out on the plain and alone' ${ }^{57}$ In this tale, primitivism was integral to Charlie's horsemanship, but it was specifically that horsemanship that was redemptive and admired.

In the following years a number of 'historical' articles about Aboriginal people began appearing in Hoofs and Horns. They were savagely racist, telling of Aborigines who had 'turned rusty and were killing white fellows and their cattle'. One story described white mounted police hunting Aboriginal people down: 'Each horseman singled out a blackfellow and appropriated him as his own particular meat'. Instead of killing a Koorie who had confronted a mounted officer, they rewarded his 'bravery' by taking him prisoner and placing him 'on the chain'. The story continues: 'This blackfellow was subsequently taught to ride and to perform police duties ... He turned out to be one of the smartest and most trustworthy of Dana's celebrated detachment of Black Police' ${ }^{58}$ It seemed that for writers and readers of Hoofs and Horns, the mark of Aboriginal capacity to be 'civilised' was the mounting of a horse. Horsemanship was civilising and display of those skills allowed admiration and transitory respect.

This research began as an attempt to illuminate the participation of Indigenous men in rodeos and travelling shows, and has raised more questions, perhaps, than it answers. Agricultural shows, touring shows and their attendant sideshows were shared spaces in southern Queensland, rural New South Wales and Victoria. Rural people, Indigenous and non-Indigenous, competed and participated in, and watched and enjoyed the range of events on offer. The history of these spaces, however, remains largely separate. Histories of Aboriginal participation in the cattle industry focus on work, both domestic labour and stockwork, and on the strategies Indigenous people employed to maintain their links with land. Aboriginal sportsmen have been paid some attention by scholars of Aboriginal Australia, and horsemen have also appeared in histories of the cattle industry and horseracing. ${ }^{59}$ These studies have made Aboriginal

\footnotetext{
Hoofs and Horns, April 1948: 50.

Hoofs and Horns, April 1948: 50.

Hoofs and Horns, April 1948: 50.

5. Hoofs and Horns, October 1949: 49.
} 
participation in sport and their sporting success visible as well as illuminating the broader, often repressive, context within which they competed. On the other hand, scholars of leisure, recreation and agricultural shows - of which sports such as horseracing and buckjumping, boxing and athletics formed a significant part - have largely focused on non-Indigenous rural communities and spectators. They argue that these forms of leisure strengthened reciprocal ties between neighbours and were integral to community building, and that from the early 20th century they represented an expression of modernity in rural life. ${ }^{60}$ Indigenous participation in these activities, however, has only been tangential to these studies, thereby effectively excluding Aboriginal sport and leisure from notions of community building and from modernity. ${ }^{61}$ Scholarship on Indigenous life in the early 20th century has shown that legislation introduced from the late 1880s attempted to control most facets of Aboriginal life, including movement, employment, marriage and, most notoriously, child rearing. Rather than community building, Indigenous people experienced a splitting of their families and communities and escalating pressure on their by-now meagre land ownership. Heather Goodall, Richard Broome and Gillian Cowlishaw, for example, have all demonstrated the bleak legislative, social and economic conditions of Aboriginal people in rural areas but, importantly for my purposes here, they have also provided evidence of Aboriginal lives continuing to be lived with spirit, imagination, humour and insight. ${ }^{62}$ This, it seems, occurred in the crevasses and spaces of the metanarrative of legislative and cultural oppression. Rural life had many such crevasses, created in part by the need for labour and the ability and willingness of Indigenous people to fulfil that need. Some of these cracks and spaces were the opportunities for recreation, competition and spectatorship that were available, albeit unequally, to both black and white. Aboriginal horsemanship was widely recognised and found a home in the multi-racial world of shows, both professional and amateur. These were many-layered events worthy of much more investigation, but from this preliminary excursion some tentative conclusions may be drawn. As Broome found in the case of boxing tents, roughriders' masculinity and horsemanship transcended racial stereotypes at bush carnivals and rodeos, and Aboriginal stockmen used these competitions to display their skills, supplement their incomes and to compete on equal terms with white riders. The broader social agenda of assimilation seeped into this world through the pages of Hoofs and Horns, where 'wild blacks' were disparaged and 'station blacks' were normalised, even admired. The stories of shows can also tell us a little more about 20th-century discourses of civilisation and primitivism, and importantly about the gendered availability of admiration, recognition, reward and respect.

59. Tatz 1995; Tatz and Tatz 2000; Corris 1980; Broome 1995; Broome 1996; Broome 1998; Broome with Jackomos 1998; Maynard 2002; Davis 2005.

60. See for example McQuilton 2001; Hunter 2004; Darian-Smith and Wills 2001; Waterhouse 2005.

61. The exceptions to this are the work of Richard Broome and Alick Jackomos on tent boxing and sideshow alley. See Broome 1995; Broome 1996; Broome 1998; Broome with Jackomos 1998. More recently, see Davis 2005 on contemporary rodeo in the Kimberley.

62. I am thinking particularly here of Heather Goodall's discussion of Aboriginal farms and reclamation of reserve land in Goodall 1996; Broome, 2005; Cowlishaw 1999. 


\section{Acknowledgements}

My thanks to Heather Goodall for her encouragement and comments, and to Richard Broome for comments on the drafts.

\section{References}

\section{Primary sources}

Crawford, Billy, interviewed by Chris Sullivan, 1989, Chris Sullivan Collection, TRC2750/569, National Library of Australia, Canberra.

Grogan, Clarry, interviewed by Kevin Bradley and Peter Ellis, 1990, TRC2604, National Library of Australia, Canberra.

Kelly, Maisie and Hazel Vale (nee Archibald), interviewed by Chris Sullivan, 1990, Chris Sullivan Collection, TRC2750/556, National Library of Australia, Canberra.

McNeven, Tom, interviewed by Chris Sullivan, 1991, Chris Sullivan Collection, TRC2750/672, National Library of Australia, Canberra.

Roberts, Tom, interviewed by Peter Byers, 1987, Chris Sullivan Collection, TRC2750/ 471, National Library of Australia, Canberra.

St Leon, Mark, nd, Index of Australian Show Movements, 1833-1956 (CD), National Library of Australia, Canberra.

Thomas, Ted, interviewed by Chris Sullivan, 1987, Chris Sullivan Collection, TRC2750/ 376, National Library of Australia, Canberra.

Newspapers:

Border Morning Mail

Hoofs and Horns

Illawarra Mercury

The Referee

\section{Secondary sources}

Bolton, Geoffrey 1981, 'Black and white after 1897', in CT Stannage (ed), A New History of Western Australia, University of Western Australia Press, Perth.

Bowen, Jill 1992 [1987], Kidman, the Forgotten King: The True Story of the Greatest Pastoral Landholder in Modern History, Angus \& Robertson, Sydney.

Brock, Peggy 1995, 'Pastoral stations and reserves in south and central Australia, 1850s-1950s', Labour History 69: 102-114.

Broome, Richard 1995, ‘Enduring moments of Aboriginal dominance: Aboriginal performers, boxers and runners', Labour History 69: 171-187.

— 1996, 'Theatres of power: tent boxing circa 1910-70', Aboriginal History 20: 1-23.

— 1998, 'Seeking Mulga Fred', Aboriginal History 22: 1-23.

— 2005, Aboriginal Victorians: A History Since 1800, Allen \& Unwin, St Leonards, New South Wales.

- (with Alick Jackomos) 1998, Sideshow Alley, Allen \& Unwin, St Leonards, New South Wales.

Cannon, Judy (with Mark St Leon) 1997, Take a Drum and Beat it: The Story of the Astonishing Ashtons, 1848-1990s, Tytherleigh Press, Kensington, New South Wales. 
Corris, Peter 1980, Lords of the Ring, Cassell, North Ryde.

Cowlishaw, Gillian 1999, Rednecks, Eggheads and Blackfellas: A Study of Racial Power and Intimacy in Australia, Allen \& Unwin, St Leonards, New South Wales.

Darian-Smith, Kate and Sara Wills 2001, 'From Queen of Agriculture to Miss Showgirl: embodying rurality in twentieth-century Australia', Journal of Australian Studies 71: 17-32.

Davis, Richard 2005, 'Eight seconds: style, performance and crisis in Aboriginal rodeo', in Deborah Bird Rose and Richard Davis (eds), Dislocating the Frontier: Essaying the Mystique of the Outback, ANU E Press, Canberra.

Goodall, Heather 1996, Invasion to Embassy: Land in Aboriginal Politics in New South Wales, 1770-1972, Allen \& Unwin, St Leonards, New South Wales.

Greenhalgh, Paul 1988, Ephemeral Vistas: The Expositions Universelles, Great Exhibitions and World's Fairs, 1851-1939, Manchester University Press, Manchester.

Grills, Ivan c1994, The Jack Stanton Story, privately published, Tamworth.

Hicks, Jenny 2000, Australian Cowboys, Roughriders and Rodeos, Harper Collins, Pymble, New South Wales.

Hunter, Kathryn M 2004, Father's Right-hand Man: Women on Australia's Family Farms in the Age of Federation, 1880s-1920s, Australian Scholarly Publishing, Melbourne.

Iverson, Peter 1994, When Indians Became Cowboys: Native Peoples and Cattle Ranching in the American West, Oklahoma University Press, Norman and London.

- and Linda MacCannell 1999, Riders of the West: Portraits from Indian Rodeo, Greystone Books, Vancouver.

Jackson-Nakano, Ann 1994, 'The Death and Resurrection of the Ngunnawal: A Living History', MLit thesis, Australian National University, Canberra.

Kidd, Rosalind 2006, Trustees on Trial: Recovering the Stolen Wages, Aboriginal Studies Press, Canberra.

Lovett-Gardiner, Iris 1997, Lady of the Lake: Aunty Iris's Story, Koorie Heritage Trust Inc, Melbourne.

Mant, Gilbert 1985, Show People, Agricultural Society of New South Wales, Parramatta.

May, Dawn 1983, From Bush to Station, James Cook University, Townsville.

- 1994, Aboriginal Labour and the Cattle Industry: Queensland from White Settlement to the Present, Cambridge University Press, Melbourne.

Maynard, John 2002, Aboriginal Stars of the Turf: Jockeys of Australian Racing History, Aboriginal Studies Press, Canberra.

McCann, Joy 2005, 'History and memory in Australia's wheatlands', in Struggle Country: The Rural Ideal in Twentieth Century Australia, Monash University e-Press, Melbourne.

McConville, Ray nd, Thorpe McConville's Wild Australia: History of a Famous Showman and the Riders Who Rode with Him, compiled by Ray McConville, Specialty Press, Albury, New South Wales.

McGrath, Ann 1987, Born in the Cattle, Allen \& Unwin, St Leonards, New South Wales.

McQuilton, John 2001, Rural Australia and the Great War: From Tarrawingee to Tangambalanga, Melbourne University Press, Melbourne. 
Oram, James 1992, The Last Showman: Larry Delahunty's Larrikin Life, Sun Books, Australia.

Poignant, Roslyn 1997, 'Looking for Tambo', The Olive Pink Society Bulletin 9(1-2): 27-37.

Pollard, Jack (ed) 1966, Horses and Horsemen, AH \& AW Reed, Wellington.

— 1970, The Horse Tamer: The Story of Lance Skuthorpe, Pollard Publishing, Wollstonecraft, New South Wales.

Ramsland, John (with Mark St Leon) 1993, Children of the Circus: The Australian Experience, Butterfly Books, Springwood, New South Wales.

Reynolds, Henry 1990, With the White People, Penguin, Ringwood.

Sampson, David 2000, 'Strangers in a Strange Land: The 1868 Aborigines and Other Indigenous Performers in mid-Victorian Britain', PhD thesis, University of Technology, Sydney.

Scott, Joanne and Ross Laurie 2007, 'Colonialism on display: Indigenous people and artefacts at an Australian agricultural show', Aboriginal History 31: 45-62.

St Leon, Mark V 2008, 'Celebrated at first, then implied and finally denied: the erosion of Aboriginal identity in circus, 1851-1960', Aboriginal History 32: 63-81.

Tatz, Colin 1995, Obstacle Race: Aborigines in Sport, University of New South Wales Press, Kensington, New South Wales.

— and Paul Tatz 2000, Black Gold: Aboriginal and Islander Sports Hall of Fame, Aboriginal Studies Press, Canberra.

Walden, Inara 1995, “"That was slavery days”: Aboriginal domestic servants in New South Wales in the twentieth century', Labour History 69: 196-209.

Walker, Faith 1997, 'The reinvention of the "noble savage": Archibald Meston and "Wild Australia"', The Olive Pink Society Bulletin 9(1-2): 37-43.

Waterhouse, Richard 2005, The Vision Splendid: A Social and Cultural History of Rural Australia, Curtin University Books with Fremantle Arts Press, Fremantle. 